\title{
Blue Ocean Strategy for creating Value of the Organization: Examination of Differentiation with Red Ocean Strategy
}

\author{
Sri Rezeki, I Gede Eko Putra Sri Sentanu, Brillyanes Sanawiri, K. Shankar, Phong Thanh \\ Nguyen
}

\begin{abstract}
For creating new demands and open up a new market space the pursuit of differentiation can be consider as Blue ocean strategy. For capturing and creating uncontested market space so it can make the irrelevant competition Blue ocean strategy is used. The Blue ocean strategy is based on the concept that industry structure and market boundaries can be reconstructed by beliefs and actions of industry members.
\end{abstract}

Keywords: Blue ocean, industry, new market space.

\section{INTRODUCTION}

In 2004 the authors named Renée Mauborgne and W. Chan Kim introduced the concept of Blue Ocean Strategy that is the theory of marketing.

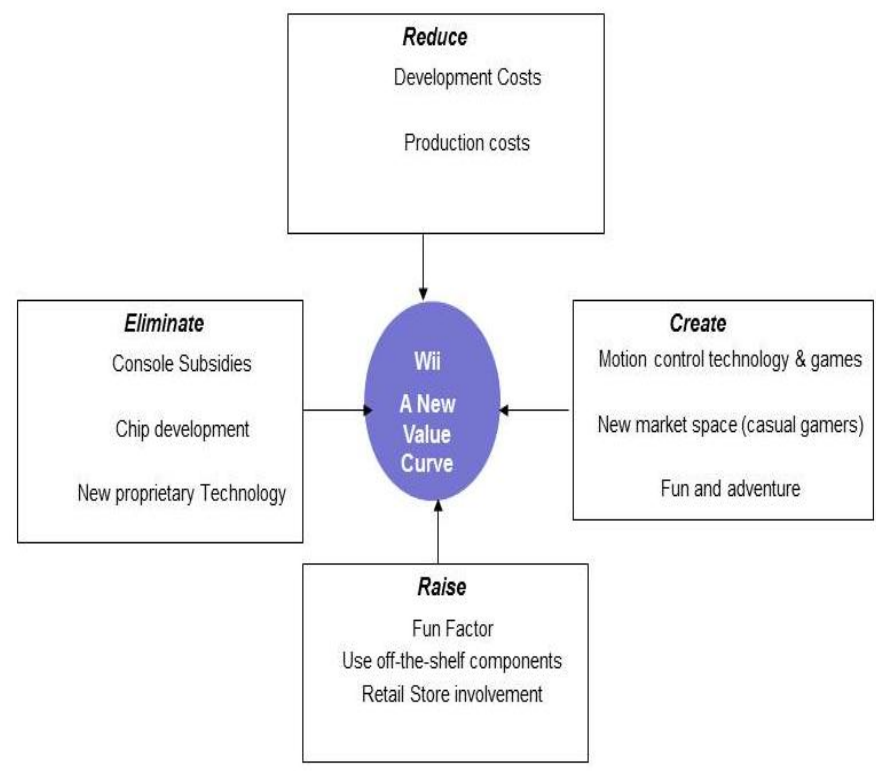

Figure 1: Blue Ocean Strategy

Renee Mauborgne and W. Chan Kim introduced the concept of evacuate shark infested waters for encouraging firms that launched a revolution in strategy of business. As making the competition irrelevant and unlocking new demand for its

Revised Version Manuscript Received on 16 September, 2019.

* Correspondence Author

Sri Rezeki, Universitas Negeri Medan, Indonesia. E-mail: audrey.th@gmail.com

I Gede Eko Putra Sri Sentanu, Universitas Brawijaya, Indonesia

Brillyanes Sanawiri, Universitas Brawijaya, Indonesia

K. Shankar, Department of Computer Applications, Alagappa University, India. E-mail: shankarcrypto@gmail.com

Phong Thanh Nguyen*, Department of Project Management, Ho Chi Minh City Open University, Vietnam. E-mail: phong.nt@ou.edu.vn employees and for its buyer these strategy uses the value of money. The book presents investigative structures and instruments to encourage an association's capacity to efficiently make and catch "blue seas"- unexplored new advertise zones. Extended versions of Blue Ocean Strategy were distributed in 2015 and 2017, separately. 


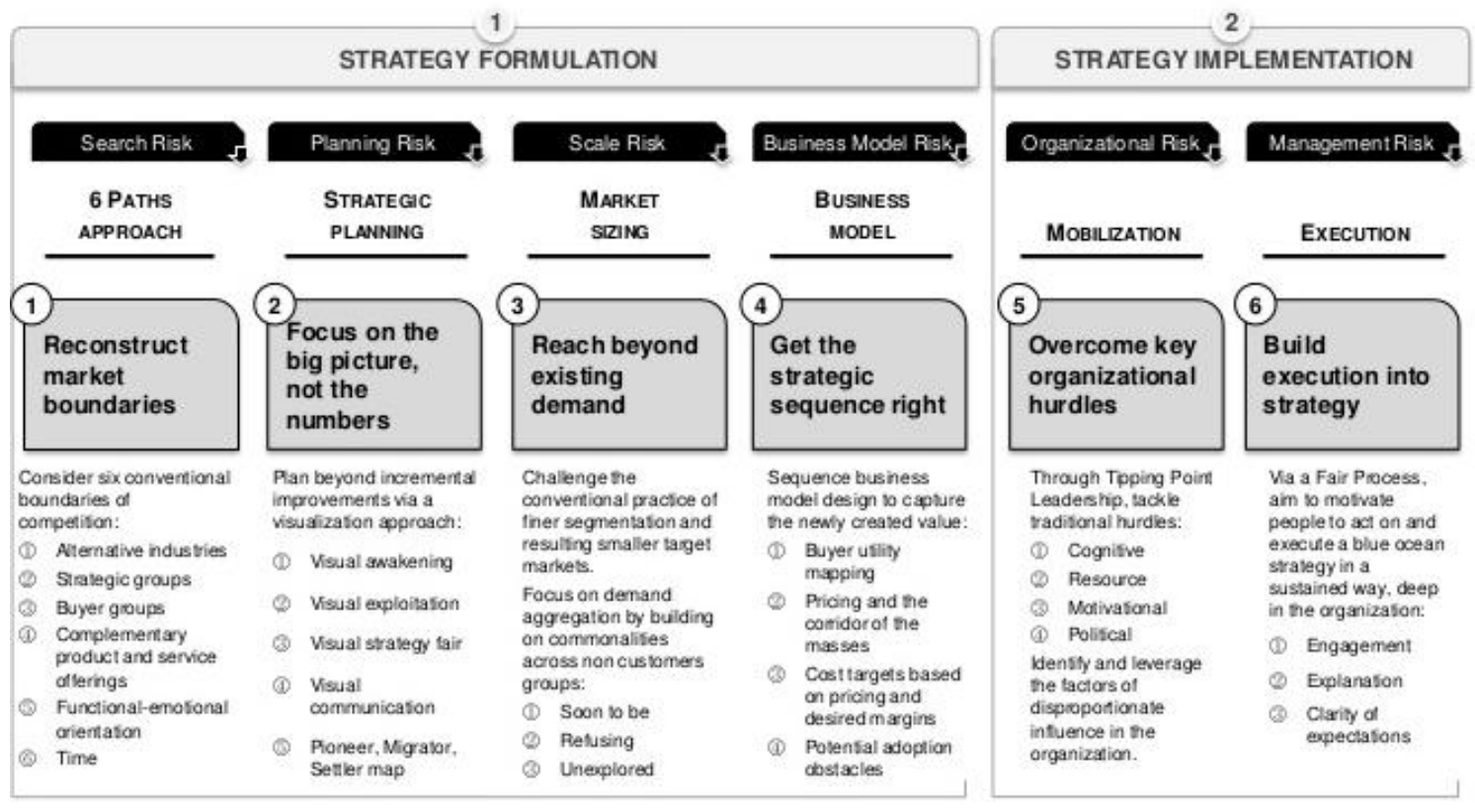

Figure 2: Blue Ocean Staregy Principle

\section{FINDING BLUE OCEANS}

While keeping away from the utilization of Harvard Business School's Michael E. Doorman's name, Kim and Mauborgne assault the popular "five powers" advertise investigation head on. Doorman's model sees explicit elements that help decide if a business can be gainful dependent on different organizations in the business.

Supporters of Kim and Mauborgne's methodology would state this is a strategy that advances savage challenge, staying in the red waters.

To find a slippery Blue Ocean, Kim and Mauborgne suggest that organizations think about what they call the Four Actions Framework to reproduce purchaser esteem components in making another worth bend. The structure suggests four key conversation starters:

Raise: What elements ought to be raised well over the business' standard?

Decrease: What elements were a consequence of going up against different enterprises and can be diminished?

Kill: Which factors that the business has since quite a while ago contended on ought to be disposed of?

Make: Which elements ought to be made that the business has never advertised?

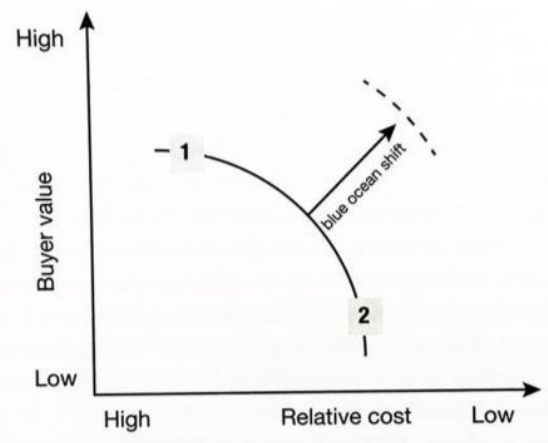

Figure 3: Marketing creating to market competing

\section{COMPONENTS OF BLUE OCEAN STRATEGY}

In a successful Blue Ocean shifts three main components are as follows:

1. Humanness: Successful implementers epitomize "a humanistic procedure, which rouses individuals' certainty to claim and drive the procedure to possess and drive the procedure for compelling execution.

2. Tools: Successful implementers of Blue Ocean methodology have utilized reasonable devices to methodicallly "make an interpretation of blue sea thinking into monetarily convincing new contributions." Sporadic, one-off "Blue Ocean technique" is a certain something: deliberately receiving Blue Ocean believing is another.

3. Mindset: The creators found that, as in the realm of Agile administration, Blue Ocean procedure is on a very basic level a move in outlook. It includes "extending mental skylines and moving comprehension of where opportunity lies."

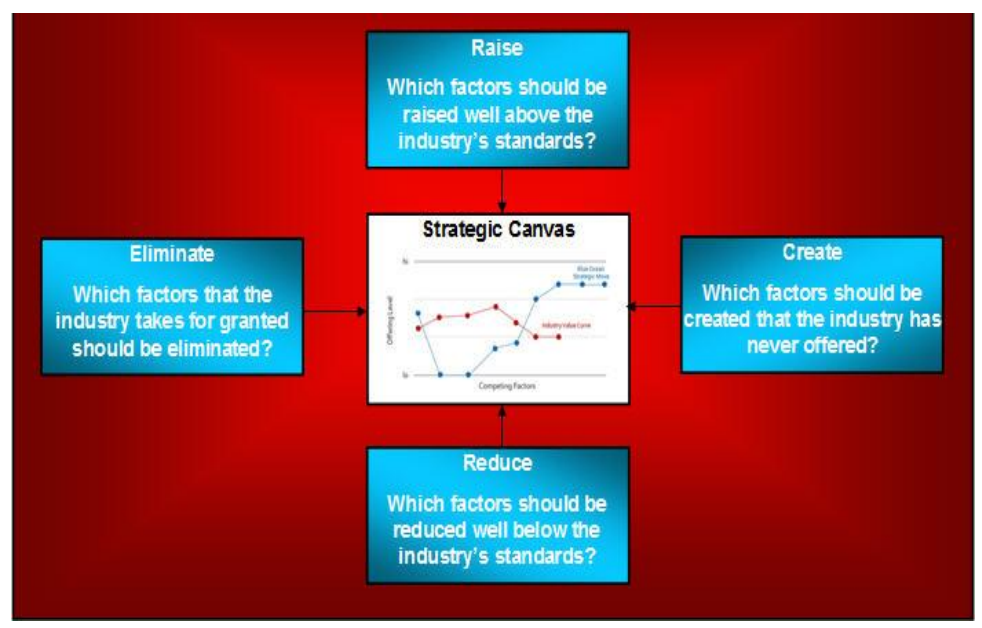

Figure 4: Actions to create Blue Ocean 


\section{EXAMPLES OF BLUE OCEAN STRATEGY}

Some organizations that successfully use the concept of blue-ocean market are described below:

1. Cirque du Soleil: This Canadian amusement organization started during the 1980s as a lot of "insane individuals" with a dream of what the cutting edge carnival could be. Customary carnival exhibitions were happy undertakings focused toward youngsters, though Cirque offered a progressively advanced involvement with a portion of the world's best entertainers.

2. Backroads: This organization transformed travel into something more testing and drawing in than the commonplace loosening up schedule of a comprehensive journey or shoreline get-away. Byways extended the business to offer something novel: extravagance dynamic travel. These fastidiously structured, wellness based outings incorporate aides who take visitors climbing, biking, outdoors, and the sky is the limit from there.

3. iTunes: When iTunes entered the market, it tackled the chronicle business' concern of customers unlawfully downloading music while all the while tending to the interest for advanced, individually tunes. iTunes' Blue Ocean Strategy made a completely new classification of music deals that enabled craftsmen to benefit and buyers to purchase single tunes versus whole collections.

\section{RED vs BLue OCEAN STRATEgY}

To describe the market universe Renée Mauborgne and W. Chan Kim use the term 'red ocean' and 'blue ocean'.
Red oceans are every one of the enterprises in presence today - the realized market space. In red seas, industry limits are characterized and acknowledged, and the focused standards of the game are known.

Here, organizations attempt to beat their opponents to snatch a more noteworthy portion of existing interest. As the market space becomes busy, benefits and development are diminished. Items become wares, prompting vicious or 'ridiculous' rivalry. Henceforth the term red oceans.

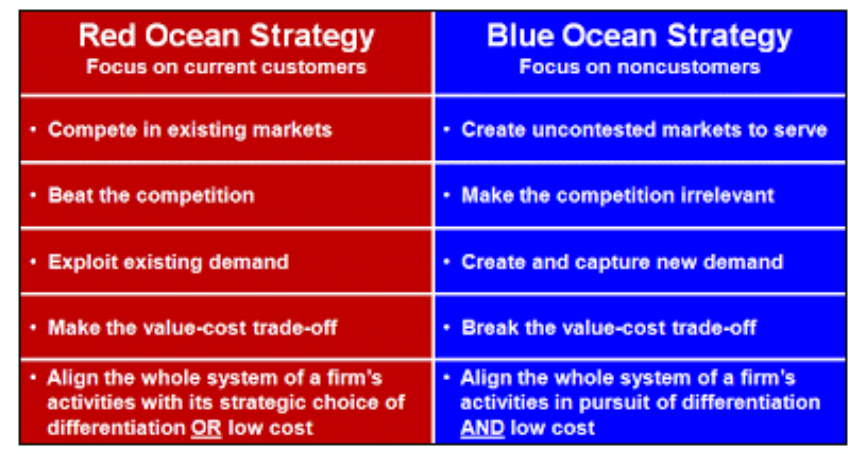

Figure 5: Rev vs. Blue Ocean Strategy

All the industries that are not in existence today denoted by Blue oceans like untainted by competition and the unknown market space. Rather than fought over demand is created in blue oceans. For rapid and profitable growth there is the opportunity is created in blue ocean.

\begin{tabular}{|c|c|c|}
\hline & Conventional Thinking & Blue Ocean Thinking \\
\hline Industry & $\begin{array}{l}\text { Industry conditions are given - } \\
\text { compete in existing market space }\end{array}$ & $\begin{array}{l}\text { Industry conditions can be shaped - } \\
\text { create uncontested market space }\end{array}$ \\
\hline Strategy & $\begin{array}{l}\text { Companies must build competitive } \\
\text { advantages to beat competition }\end{array}$ & Make competition irrelevant \\
\hline Market & Exploit existing demand & Create and capture new demand \\
\hline Resources & Make the value-cost trade-off & Break the value-cost trade-off \\
\hline Organization & $\begin{array}{l}\text { Align the whole system of a firm's } \\
\text { activities with its strategic choice of } \\
\text { differentiation or low cost }\end{array}$ & $\begin{array}{l}\text { Align the whole system of a firm's } \\
\text { activities in pursuit of differentiation and } \\
\text { low cost }\end{array}$ \\
\hline Offerings & $\begin{array}{l}\text { Maximizing the offering's value within } \\
\text { industry boundaries }\end{array}$ & $\begin{array}{l}\text { Offering buyers the total solution that } \\
\text { transcends the industry }\end{array}$ \\
\hline
\end{tabular}

Table 1: Difference between conventional and blue ocean thinking 


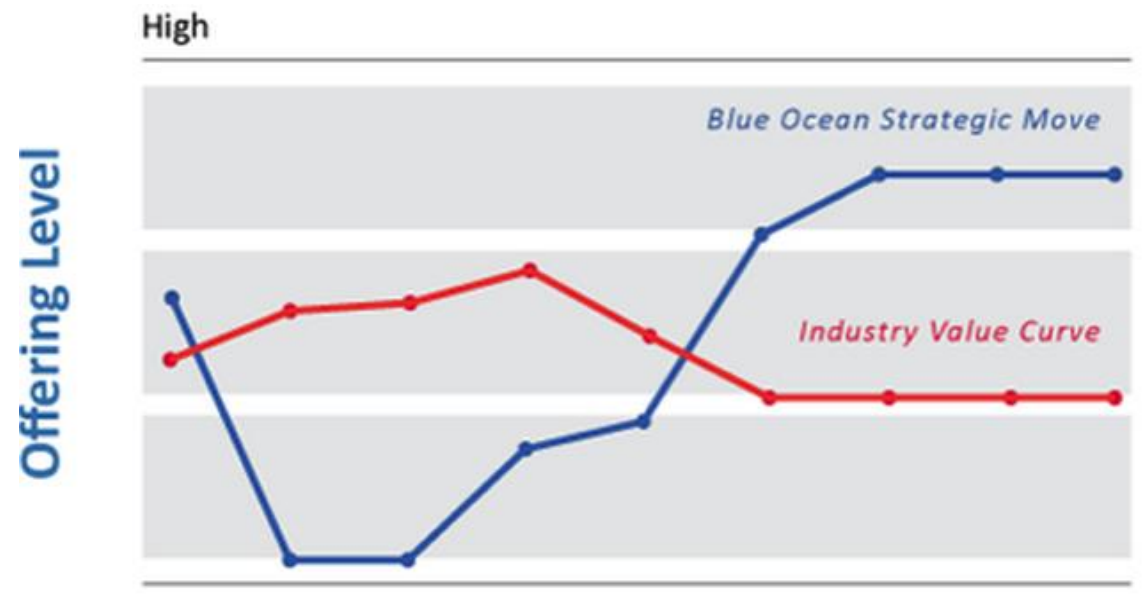

Low

\section{Competing Factors}

Figure 6: Blue Ocean Strategy Move

\section{CONClusion}

'Blue Ocean Strategy is alluded to a business opportunity for an item where there is no challenge or less challenge. This procedure rotates around scanning for a business in which not many firms work and where there is no valuing weight. In the present condition most firms work under exceptional challenge and attempt to do everything to pick up piece of the pie. At the point when the item goes under valuing weight there is constantly a likelihood that a company's tasks could all around go under risk. This circumstance as a rule comes when the business is working in a soaked market, otherwise called 'Red Ocean'. The system plans to catch new request, and to make rivalry unessential by presenting an item with unrivaled highlights. It enables the organization in make gigantic benefits as the item to can be valued somewhat soak in view of its remarkable highlights.

\section{REFERENCES}

1. Jermsittiparsert, K., Siam, M., Issa, M., Ahmed, U., \& Pahi, M. 2019. "Do Consumers Expect Companies to Be Socially Responsible? The Impact of Corporate Social Responsibility on Buying Behavior." Uncertain Supply Chain Management 7 (4): 741-752.

2. Syazali, M., Putra, F., Rinaldi, A., Utami, L., Widayanti, Umam, R., \& Jermsittiparsert, K. 2019. "Partial Correlation Analysis Using Multiple Linear Regression: Impact on Business Environment of Digital Marketing Interest in the Era of Industrial Revolution 4.0." Management Science Letters 9 (11): 1875-1886.

3. Sae-Lim, P. \& Jermsittiparsert, K. 2019. "Is the Fourth Industrial Revolution a Panacea? Risks toward the Fourth Industrial Revolution: Evidence in the Thai Economy." International Journal of Innovation, Creativity and Change 5 (2): 732-752.

4. Kim, W.C.; Mauborgne, R. (2004). Blue Ocean Strategy: How to Create Uncontested Market Space and Make the Competition Irrelevant. Boston: Harvard Business School Press. ISBN 978-1591396192.

5. Haseeb, M., Hussain, H., Slusarczyk, B., \& Jermsittiparsert, K. 2019. "Industry 4.0: A Solution towards Technology Challenges of Sustainable Business Performance.” Social Sciences 8 (5): 184.

6. Haseeb, M., Hussain, H., Kot, S., Androniceanu, A., \& Jermsittiparsert, K. 2019. "Role of Social and Technological Challenges in Achieving a Sustainable Competitive Advantage and Sustainable Business Performance." Sustainability 11 (14): 3811.

7. Haseeb, M., Kot, S., Hussain, H., \& Jermsittiparsert, K. 2019. "Impact of Economic Growth, Environmental Pollution, and Energy Consumption on Health Expenditure and R and D Expenditure of ASEAN Countries." Energies 12 (19): 3598.

8. Huda, S., Tsani, I., Syazali, M., Umam, R., \& Jermsittiparsert, K. 2020 "The Management of Educational System Using Three Law Auguste Comte: A Case of Islamic Schools.” Management Science Letters 10 (3) (In press), DOI: 10.5267/j.msl.2019.9.018.

9. Usak, M., Kubiatko, M., Shabbir, M., Dudnik, O., Jermsittiparsert, K., \& Rajabion, L. 2019. "Health Care Service Delivery Based on the Internet of Things: A Systematic and Comprehensive Study." International Journal of Communication Systems 32 (14): e4179.

10. Kim, W.C.; Mauborgne, R. (2017). Blue Ocean Strategy with Harvard Business Review Classic Articles "Blue Ocean Leadership" and "Red Ocean Traps" (3 Books). Boston: Harvard Business School Press.

11. Chienwattanasook, K., Wattanapongphasuk, W., Prianto, A., \& Jermsittiparsert, K. 2019. "Corporate Entrepreneurship and Business Performance of Logistic Companies in Indonesia." Industrial Engineering \& Management Systems 18 (3): 538-547.

12. Dawabsheh, M., Hussein, A., \& Jermsittiparsert, K. 2019. "The Triangular Relationship between TQM, Organizational Excellence and Organizational Performance: A Case of Arab American University Palestine." Management Science Letters 9 (6): 921-932.

13. Chatchawanchanchanakij, P., Arpornpisal, C., \& Jermsittiparsert, K. 2019. "The Role of Corporate Governance in Creating a Capable Supply Chain: A Case of Indonesian Tin Industry." International Journal of Supply Chain Management 8 (3): 854-864.

14. "'Nắng tháng 8', 'Biển và chim bói cá' đoạt giải Sách hay 2013". VietBao. September 22, 2013. Retrieved March 18, 2014.

15. Fukolova, Julia (December 3, 2012). "Bestseller of all times". kommersant.ru. Retrieved March 21, 2014.

16. Jermsittiparsert, K., Namdej, P., \& Somjai, S. 2019. "Green Supply Chain Practices and Sustainable Performance: Moderating Role of Total Quality Management Practices in Electronic Industry of Thailand." International Journal of Supply Chain Management 8 (3): 33-46.

17. Somjai, S. \& Jermsittiparsert, K. 2019. "The Trade-off between Cost and Environmental Performance in the Presence of Sustainable Supply Chain." International Journal of Supply Chain Management 8 (4): 237-247.

18. Jermsittiparsert, K. \& Sawasdee, A. 2012. "Formal Education for Non-Thai or Undocumented Person in Thailand amidst the Challenge of Nationalism and Transnationalism: A Case Study of Wat Sirimongkhol School, Samut Sakhon Province." Kasetsart Journal Social Sciences 33 (2): 203-213.

19. "Harvard Business Review Readers Choose the Best Management Books 2013". Diamond Harvard Business Review. October 8, 2013 Retrieved March 18, 2014.

20. Mintzberg, H. and J.B. Quinn, 1991. The Strategy Process: Concepts, Context, Cases. Englewood Cliffs,New Jersey: Prentice-Hall.

21. Jermsittiparsert, K., Ambarita, D., Mihardjo, L., \& Ghani, E. 2019. "Risk-Return through Financial Ratios as Determinants of Stock Price: A Study from ASEAN Region.” Journal of Security and Sustainability Issues 9 (1): 199-210. 
22. Thabhiranrak, T. \& Jermsittiparsert, K. 2019. "Towards Sustainable Functioning of Organization: Women Empowernment and Corporate Management Culture.” Journal of Security and Sustainability Issues 9 (1): 321-332.

23. Chienwattanasook, K. \& Jermsittiparsert, K. 2019. "Impact of Entrepreneur Education on Entrepreneurial Self-Employment: A Case Study from Thailand." Polish Journal of Management Studies 19 (1): 106-116.

24. Jermsittiparsert, K., Sutduean, J., Sriyakul, T., \& Khumboon, R. 2019. "The Role of Customer Responsiveness in Improving the External Performance of an Agile Supply Chain." Polish Journal of Management Studies 19 (2): 206-217.

25. Management Decision, 40(7): 663-71.Porter, M., 1980. Competitive Strategy. Free Press, New York.

26. Wall, S.J. and S.R. Wall, 1995. The Evolution (Not the Death) of Strategy. Organizational Dynamics,24(2): 7-19.

27. Mintzberg, H., 1990. "The design school: reconsidering the basic premises of strategic management",Strategic Management Journal, 11(3): 171-95.

28. Jarzabkowski, P.A. and D.C. Wilson, 2006. Actionable strategy knowledge: A practice perspective.European Management Journal, 24(5): 348-67Aust. J. Basic \& Appl. Sci., 5(7): 86-91, 201191

29. Hartinah, S., Suharso, P., Umam, R., Syazali, M., Lestari, B., Roslina R., \& Jermsittiparsert, K. 2020. “Teacher's Performance Management: The Role of Principal's Leadership, Work Environment and Motivation in Tegal City, Indonesia." Management Science Letters 10 (1): $235-246$

30. Jermsittiparsert, K., Sutduean, J., \& Sriyakul, T. 2019. "Effect of Service Innovation and Market Intelligence on Supply Chain Performance in Indonesian Fishing Industry.” Industrial Engineering \& Management Systems 18 (3): 408-417.

31. Chaharbaghi, K. and R. Willis, 1998. Strategy: the missing link between continuous revolution and constantevolution. International Journal of Operations and Production Management, 18(9/10): 1017-27.

32. Wall, S.J. and S.R. Wall, 1995. The Evolution (Not the Death) of Strategy. Organizational Dynamics,24(2): 7-19.

33. Roth, S.; et al. (2018). "Multifunctional organisation models. A systems-theoretical framework for new venture discovery and creation". Journal of Organizational Change Management. 31: $1383-1400$. 